DOI

\title{
ДОСЛІДЖЕННЯ ЯКІСНИХ ОСОБЛИВОСТЕЙ ФАРМАЦЕВТИЧНОГО ЗАБЕЗПЕЧЕННЯ ХВОРИХ НА ЦИРОЗИ ПЕЧІНКИ ІЗ ВСТАНОВЛЕНИМИ УСКЛАДНЕННЯМИ ОСНОВНОГО ДІАГНОЗУ
}

\author{
ОІ. О. Федяк, О. В. Максименко, *Н. В. Шолойко \\ ДВНЗ «Івано-Франківський національний медичний університет» \\ *Національний медичний університет імені О. О. Богомольця
}

РЕЗЮМЕ. У статті наведено результати частотного аналізу листків призначень хворих на цирози печінки різної етіології. Вони вказують, що препарати, які були спожиті пацієнтами в умовах стаціонару, насамперед призначалися для лікування ускладнень основного діагнозу. Встановлено, що гепатоцелюлярна недостатність різного ступеня спостерігалася у 94 \% пацієнтів, портальна гіпертензія - у 87,4 \%, асцит -у 37,9 \%. Тому найчастіше призначали: Верошпірон (Gedeon Richter Plc., Угорщина) - отримали 64,2 \% пацієнтів, Тіогама Typ6o (Woerwag Pharma GmbH \& Co. KG, Німеччина) - 45,8 \% та Дуфалак (Solvay Pharmaceuticals B.V., Нідерланди) - 41 \% хворих.

КЛЮчОВІ СЛОВА: цирози печінки; ускладнення цирозу печінки; частотний аналіз; лікарські засоби, що застосовуються при захворюваннях печінки.

Вступ. При всіх варіантах цирозів печінки (ЦП) прогноз дуже серйозний і визначається ступенем морфологічних змін в печінці, тенденцією захворювання до прогресування і відсутністю ефективних методів терапії. 5-річне виживання після вперше діагностованого ЦП складає 50-60\%, після першого прояву ускладнень цей показник різко знижується до 5 \%. Головні передумови загибелі при ЦП-печінкова кома і кровотеча з верхніх відділів шлунково-кишкового тракту. Усунення причин, які сприяють прогресуванню захворювання і виникненню декомпенсації, покращує прогноз і збільшує тривалість життя хворого [1, 2]. За останні 6 років кількість хворих на ЦП в Україні зросла на 9,5 \%, причому лікарняна летальність хворих зросла аж на $19 \%$ [3]. Тому питання доказової та економічно обґрунтованої фармакотерапії пацієнтів із ЦП є актуальними в Україні на даний час.

Питання поширеності та особливостей перебігу ЦП серед чоловіків та жінок, а також аналізу показників фіброзування печінки у хворих на субкомпенсований цироз висвітлювались у роботах О. Є. Самогальської, Т. Б. Лазарчук, Н. М. Олійник $[1,4]$. Проблеми діагностики і лікування хронічних невірусних захворювань печінки розглядали В. Є. Нейко, Н. Г. Вірстюк, О. І. Дєльцова [2], аналіз результатів стаціонарного лікування хворих із хронічними дифузними захворюваннями печінки в Тернопільській області проводили І. Я. Дзюбановський, Т. В. Романюк [5].

У тезах «Частотний аналіз лікарських засобів, призначених для лікування цирозу печінки в лікарні міста Харкова» (О. В. Ткачова, К. О. Мінова) був представлений частотний аналіз фармакотерапії хворих на ЦП в м. Харкові [6]. Результати даного дослідження, проведеного в аналогічний часовий проміжок, є синонімічними із результатами нашої роботи, у якій зроблено більший акцент саме на зв'язок призначення із наявністю ускладнень основного захворювання та їх характеристику.

Мета дослідження: ранжування ускладнень пацієнтів із ЦП, а також проведення частотного аналізу спожитих ними лікарських засобів (ЛЗ).

Матеріал і методи дослідження. Предмет дослідження - 190 медичних карток стаціонарних хворих гастроентерологічного відділення ІваноФранківської обласної клінічної лікарні за 20122013 рр. Як методологічний інструмент був використаний ретроспективний частотний аналіз.

Результати й обговорення. Насамперед був проведений розподіл пацієнтів за гендерною ознакою, віком, соціальним станом. Встановлено, що за 2012 рік проліковано 85 осіб, а 2013 року - 105; осіб чоловічої статі було 129 (67,9\%), а жіночої- 61 (32,1 \%). Отримані дані свідчать, що кількість хворих на ЦП чоловічої статі працездатного віку становить $86 \%$, а жіночої - 81 \%. Серед чоловіків та жінок найбільше хворіли у віці від 51 до 60 років. Серед осіб, які проходили лікування, були різні соціальні прошарки, а саме: безробітні - 30 \% (чол. $72 \%$, жін. 28 \%), інваліди - 18,4 \% (чол. $71 \%$, жін. $29 \%$ та службовці - 18,4\% (чол. 77 \%, жін. $23 \%$ ), менше було пенсіонерів - 17,4 \% (чол. 48 \%, жін. $52 \%$ ), робітників - 14,7 \% (чол. 68 \%, жін. 32 \%) та учасників бойових дій - 1,1\% (чол. $100 \%$ ).

Отже, аналіз медичних карток стаціонарних хворих підтвердив високий рівень захворюваності на ЦП серед працездатного населення незалежно від роду діяльності. Було встановлено, що більшість пацієнтів, стаціонарні медичні картки яких сформували досліджувану вибірку, хворіють на змішаний $(44,2$ \%) та криптогенний $(38,4 \%)$ ЦП (рис. 1). 


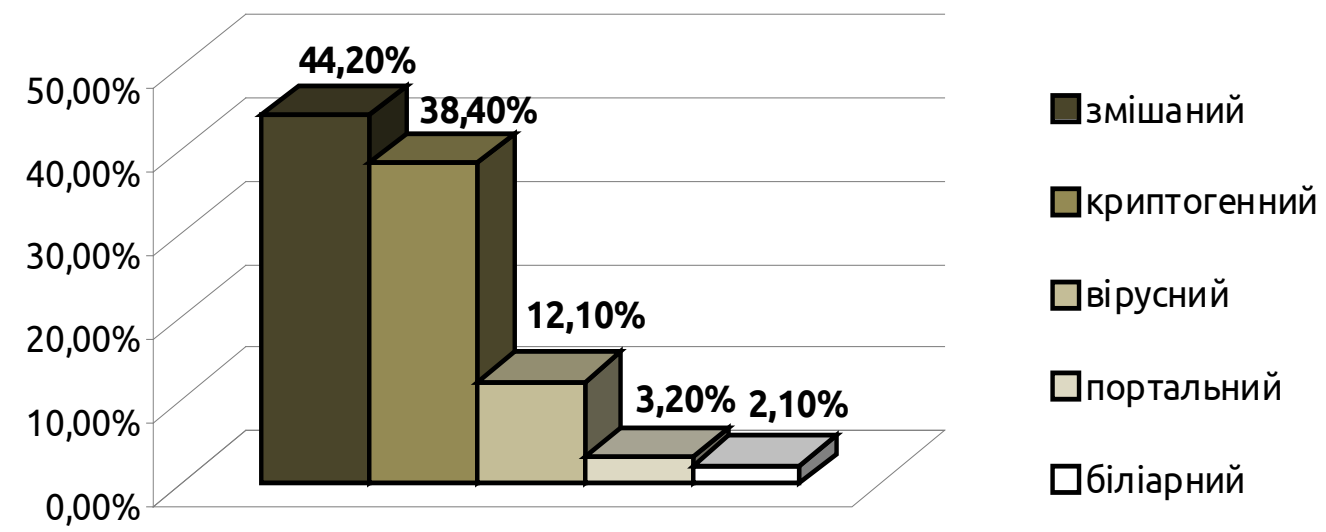

Рис. 1. Розподіл пацієнтів із цП за етіологічними видами цирозу.

При аналізі медичних карток було встановлено, що неускладненого перебігу основного захворювання не мав жоден пацієнт. У всіх хворих були наявні ускладнення ЦП різного ступеня. Так, синдром портальної гіпертензії діагностовано у 166 пацієнтів (87,4 \%): II ступеня - у 145 (87 \%) хворих і III ступеня - у 21 (13\%). Найпоширенішим і найважливішим симптомом портальної гіпертензії $\epsilon$ асцит, який діагностували у 72 осіб із ЦП, що становить 37,9 \% усіх хворих і 43,3 \% паці$\epsilon$ нтів із портальною гіпертензією. Отримані дані корелюють із даними літературних джерел, які стверджують, що у майже половини пацієнтів із синдромом портальної гіпертензії спостерігається дане ускладнення [5]. Препаратами вибору при набряково-асцитному синдромі $\epsilon$ калійзберігаючі діуретики.

Варикозне розширення вен стравоходу, як прояв синдрому портальної гіпертензії, встановлено у 46 хворих на ЦП, що становило 24,2 \% всіх пацієнтів. Окрім цього, у половини хворих мала місце кровотеча з варикозно розширених вен стравоходу [5]. Також, як наслідок крововтрати, розвивається вторинна анемія, яку діагностовано у 25 пацієнтів. Ще одним проявом портальної гіпертензії $\epsilon$ спленомегалія, яку виявили у 23 хворих, що становило 12 \% всіх досліджуваних пацієнтів.

Важливим діагностичним критерієм $\epsilon$ визначення функціонального стану печінки у хворих на ЦП [7-9]. Так, різні ступені гепатоцелюлярної недостатності було діагностовано у 179 пацієнтів, що склало 94 \%: І ступеня - у 17 (9,5\%) хворих, II ступеня - у 156 (87 \%) і III ступеня - 6 (3,5 \%). При цьому ускладнення печінковою енцефалопатією зареєстровано у 37 (19,5 \%) осіб із ЦП. Крайню форму печінковоклітинної недостатності-гепаторенальний синдром - виявлено у 25 пацієнтів.

Як свідчать отримані дані, хворі зверталися за стаціонарною допомогою у тяжкому стані. Тому наявність ускладнень основної патології і присут- ність супутніх хвороб поряд із ЦП у аналізованої вибірки хворих збільшило число призначень ЛЗ, а це, у свою чергу, призвело до збільшення навантаження на основну детоксикаційну лабораторію організму.

У подальшому був зроблений ретроспективний частотний аналіз призначень пацієнтам із ЦП. Встановлено, що сумарно 190 пацієнтам було зроблено 1968 призначень Л3 - в середньому 1011 призначень на одну медичну картку. Частотний аналіз виявив, що пацієнтам було призначено 197 найменувань ЛЗ за торговими назвами. На рисунку 2 представлено ТОП-15 ЛЗ за частотою використання та їх внеском у загальну сукупність призначень.

Отже, найчастіше для лікування хворих із ЦП був використаний препарат Верошпірон капс. 100 мг № 30 (Gedeon Richter Plc., Угорщина), який отримали 122 пацієнти (64,2 \%), але враховуючи велику кількість призначень, займав у загальній сукупності призначень 6,2 \%; на другому місці Тіогама Турбо р-н д/іф. 1,2 \% № 1 (Woerwag Pharma $\mathrm{GmbH} \&$ Co. KG, Німеччина), що був призначений 87 пацієнтам (45,8 \%) - 4,42 \% призначень; на третьому - Дуфалак сироп, 667 г/1000 мл 500 мл (Solvay Pharmaceuticals B.V, Нідерланди), який був спожитий 78 особами - 3,69 \% призначень.

Як виявив аналіз, у ТОП-15 ЛЗ, які найчастіше отримували хворі на ЦП, присутні лише 5 гепатопротекторів (базисна терапія відповідно до Клінічного протоколу надання медичної допомоги хворим на цирози печінки), а саме: Тіогама Турбо р-н д/iф. 1,2 \% № 1 (Woerwag Pharma GmbH \& Co. KG, Німеччина), Гептрал пор. ліофіл. д/пригот. р-ну д/ін. 400 мг № 5 (Ноspiга, Італія), Глутаргін конц. д/пригот. р-ну д/інф. 40\% 5 мл № 10 (ФК Здоров'я, Україна), Ессенціале р-н д/ін. 250 мг/5 мл № 5 (A. Nattermann \& Cie, Німеччина), Тіотріазолін р-н д/ін. 2,5\% амп. 2 мл № 10 (Київмедпрепарат, Україна). Інші ЛЗ використовували при ускладненнях ЦП та супутніх захворюваннях. Тому до складу спожи- 


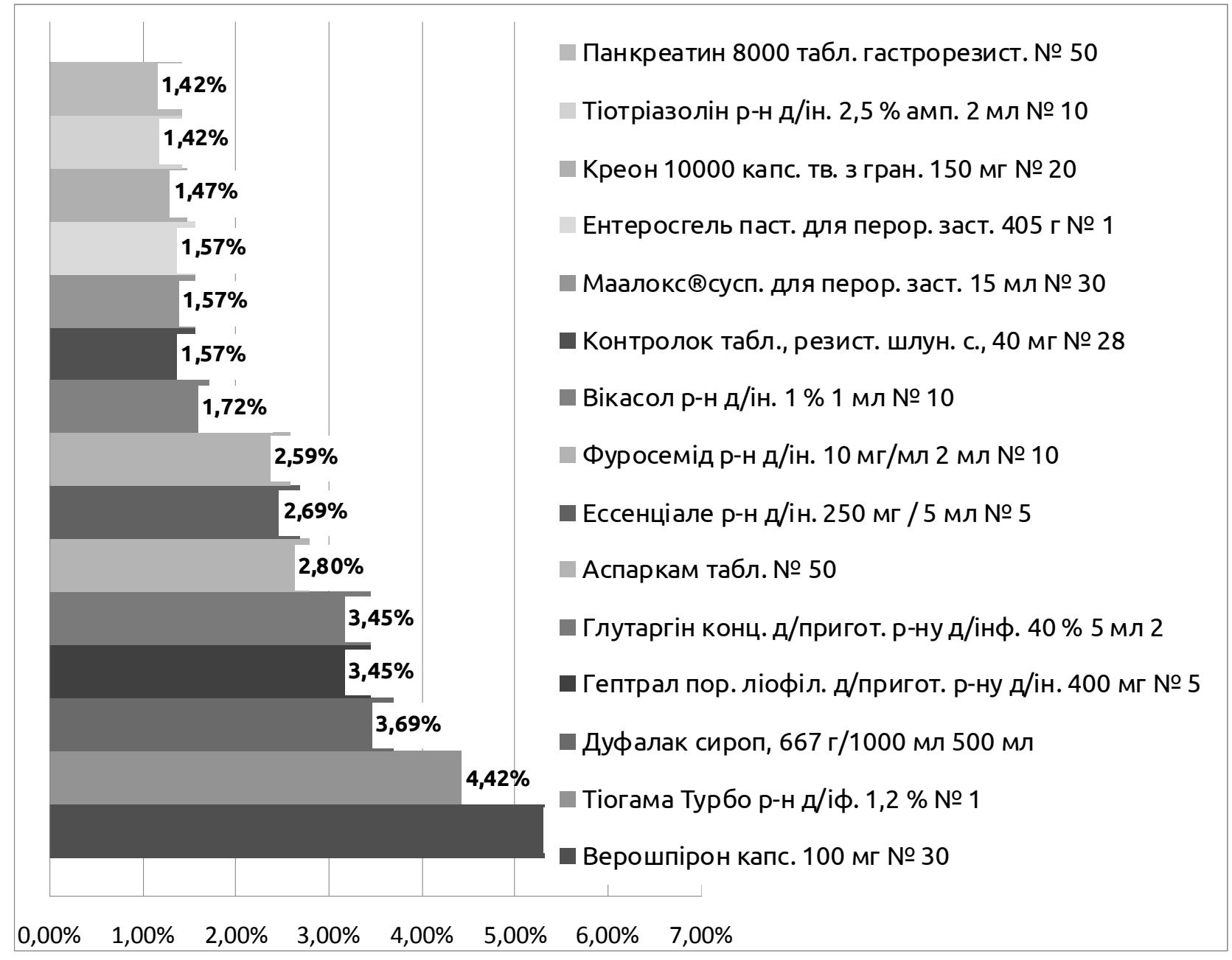

Рис. 2. ТОП -15 Л3, які найчастіше отримували хворі на цироз печінки.

тої зазначеною категорією пацієнтів фармакотерапії, крім власне гепатопротекторів, увійшли діуретики - для лікування асциту (Верошпірон (Richter Gedeon Ltd, Угорщина), Фуросемід (Борщагівський ХФЗ, Україна), Трифас 10 (Berlin-chemie AG, Німеччина), Гіпотіазид («CHINOIN», Pharmaceutical and Chemical Works Co.Ltd., Угорщина), Урегід («Egis» Pharmaceutical Ltd, Угорщина) - вони становлять $12,96 \%$ усієї сукупності призначень, а їх отримали 134,2 \% хворих, що свідчить про те, що деяким пацієнтам одночасно призначали 2 діуретики); препарати лактулози - для лікування печінкової енцефалопатії (Дуфалак, Solvay Pharmaceuticals B.V., Нідерланди), Нормолакт (Борщагівський ХФЗ, Україна) - 4,37 \% призначень, 45,2 \% пацієнтів); антиаритмічні препарати - з метою відновлення калію та магнію в організмі (Аспаркам (Галичфарм, Україна), Панангін (Richter Gedeon Ltd, Угорщина) 4,57 \% призначень, 47,4 \% пацієнтів); група вітаміну К та інші гемостатичні засоби - для зупинки кровотечі (Вікасол (Біостимулятор, Україна), Діцинон
(Lek, Словенія) - 3,05 \% призначень, 31,6 \% пацієнтів); ферменти - з метою покращення травлення (Креон (Solvay Pharmaceuticals $\mathrm{GmbH}$, Німеччина), Панкреатин (Технолог ПрАТ, Україна), Пангрол (Berlin-chemie AG, Німеччина), Мезим форте (Berlinchemie AG, Німеччина) - 4,98 \% призначень, 51,6 \% пацієнтів).

Висновки. За результатами аналізу медичних карток стаціонарних хворих на цирози печінки різної етіології встановлено, що усі пацієнти мали ускладнення основного діагнозу. Серед них переважали: гепатоцелюлярна недостатність різного ступеня (94\%), портальна гіпертензія $(87,4 \%)$ та асцит $(37,9 \%)$, для лікування яких були призначені сечогінна (12,96 \%), антитоксична (5,94\%), ферментна (4,98 \%) складові фармакотерапії поряд із власне гепатопротекторами (28,04 \% усіх призначень).

Перспективи подальших досліджень. Враховуючи тенденцію до постійного зростання захворюваності, тяжкості перебігу, зокрема серед 
Огляди літератури, оригінальні дослідження, погляд на проблему

осі6 працездатного віку (відсоток яких серед усіх пацієнтів становить близько 85 \%), лікування ускладнень ЦП є важливою проблемою, яка потребує подальшого глибокого вивчення та пошу- ку шляхів адекватної медикаментозної корекції з врахуванням результатів інших видів ретроспективного клініко-економічного та власне фармакоекономічного аналізу.

\section{ЛІТЕРАТУРА}

1. Аналіз показників фіброзування печінки у хворих на субкомпенсований цироз / О. Є. Самогальська, Т. Б. Лазарчук, Н. М. Олійник [та ін.] // Вісник наукових досліджень. - 2012. - № 2. - С. 29-31.

2. Діагностика і лікування хронічних невірусних захворювань печінки / В. Є. Нейко, Н. Г. Вірстюк, О. І. Дєльцова [та ін.] // Реферат науково-дослідної роботи. 2010. -7 c.

3. Федяк І. О. Результати аналізу використання гепатопротекторів у хворих на цироз печінки / І. О. Федяк, О. В. Максименко // Здобутки та перспективи управління фармацевтичною системою: матер. наук.-практ. конференції з міжнародною участю присвяченої 50-літтю створення кафедри ОЕФ ЛНМУ ім. Данила Галицького. - Львів : Растр-7, 2014. - С. 162-164.

4. Самогальська О. Є. Порівняльний аналіз поширеності та особливостей перебігу цирозу печінки серед чоловіків та жінок // Вісник наукових досліджень. 2008. - № 2. - С. 19-21.

5. Дзюбановський І. Я. Ретроспективний аналіз результатів стаціонарного лікування хворих із хронічними дифузними захворюваннями печінки в Тернопільській області / І. Я. Дзюбановський, Т. В. Романюк // Вісник наукових досліджень. - 2014. - № 2. - С. 18-19.

6. Ткачова О. В. Частотний аналіз лікарських засобів, призначених для лікування цирозу печінки в лікарні міста Харкова / О. В. Ткачова, К. О. Мінова // Матеріали VII наук.-практ. конф. "Фармакоекономіка в Україні: стан та перспективи розвитку». - Х. : Вид-во НфаУ, 2014. - C. 55-56.

7. Runyon Br. A. Introduction to there vised American Association for the Study of Liver Diseases Practice Guideline managemen to fadult patients with ascitesdue to cirrhosis 2012 / Br. A. Runyon // Hepatology. - 2013. Vol 57. - P. 1651-1653.

8. Schuppan D. Liver Cirrhosis / D. Schuppan, N. Afdhal // Lancet. - 2008.- Vol. 371. - P. 838-851.

9. Risk factors and comorbidities in primary biliary cirrhosis: A controlled interview-based studyof 1032 patients / M. E. Gershwin, C. Selmi, H. J. Worman [et al.] // Hepatology. - 2005. - Vol. 42. - P. 1194-1202.

\title{
RESEARCH OF QUALITATIVE FEATURES OF PHARMACEUTICAL PROVIDING TO PATIENTS WITH LIVER CIRRHOSIS WITH ESTABLISHED COMPLICATIONS OF MAIN DAGNOGOSIS
}

\author{
@I. O. Fedyak, O. V. Maksymenko, *N. V. Sholoyko \\ Ivano-Frankivsk National Medical University \\ * National Medical University by O. O. Bohomolets
}

SUMMARY. This article presents the results of implemented frequency analysis of medical prescriptions of patients with liver cirrhosis of different etiologies. They indicate that the drugs that have been taken by patients in the hospital conditions, primarily used to treat complications of basic diagnosis. Since it has been established that hepatocellular insufficiency of different level was observed in $94 \%$ of patients, portal hypertension - in $87.4 \%$, ascites - in $37.9 \%$. Therefore, the most often prescribed drugs were: Verospiron (Gedeon Richter, Hungary) was prescribed to $64.2 \%$ of patients, Tiogama Turbo (Wörwag Pharma GmbH \& Co, Germany) was taken ин 45.8 \% of patients and Duphalac syrup (Solvay Pharmaceuticals, the Netherlands) $-41 \%$ of patients.

KEY WORDS: liver cirrhosis, primary diagnosis complications, frequency analysis, drugs used to treat liver diseases.

Отримано 22.10.2015 